EBO SOCRATES,

Institute of Foundation Studies, Federal University Otuoke (Bayelsa State, Nigeria)

e-mail: eboss@fuotuoke.edu.ng, ORCID0000-0003-4062-8487

\title{
THE "MATSER" MADE WORLD: A NEW CONCEPTUALIZATION OF MATTER AND SPIRIT
}

The world has always been, and will always be a fascinating enigma to man. Generations of thinkers have struggled to fathom the world and explain it in an intelligible formation. Till date, a thoroughly satisfactory explanation of the cosmos has not been finagled. The search for a comprehensive explanation of the world continues. Dominating the interpretations of the world are the materialistic and idealistic schools of thought. These are diametrically opposed cosmological systems without a middle ground. The materialists see the world as essentially material, devoid of any god or maker. The idealists see the world as a product of a spirit or mind. They believe the world to be fundamentally non-material in nature. Nkrumah, a thorough going materialist, believes the world to be fundamentally material in nature, Berkeley who was the most radical advocate of idealism, however, believes the world to be fundamentally spiritual. But the cosmos is, irrespective of man's interpretation of it. It is fundamentally one in our experience. The problem lies with our conception of some phenomena as material; and some others as spiritual. How can the material and non-material interact? If the world is material, it is definitely not spiritual. If it is made of ideas only, it is definitely not material. But supposing the world is neither material nor spiritual? It could as well be that our definition of matter does not encompass some of the properties inherent in the phenomena we regard as 'matter". It could as well be that what we refer as "spiritual" are properties inherent in but not encompassed by the definition of what we call matter. We could as well be living in a "matserial" cosmos, a world that is fundamentally made up of substances whose properties include those we conceive as "material" and some of those we consider as "spiritual". Perhaps it is time to re-examine our concept of matter and our concept of spirit. Perhaps, we should be talking of "matser" rather than matter and spirit. This work is a product of library research, philosophical analysis and systematic philosophical speculation. It addresses the problem of the interpretation of the world which encompasses the problem of language and the mind/matter dichotomy. It is the finding of this work that the cosmos is neither made up solely of matter or spirit. Phenomena exhibit characteristics which we traditionally describe as spiritual and material. Our conceptualizations of mind and spirit logically leads to a dual cosmos of mind and spirit, which obviously is fallacious. We are in one cosmos. The cosmos is only doubled in our language, not in our experience. Our experience of the cosmos remains one. It is the recommendation of this work that "matser" rather than mind and spirit should be used to characterize phenomena. Ours is a matserial cosmos.

Keywords: Cosmos-Knowing Subject; Ideas-made World; Berkeley; Matter-made World; Nkrumah; Re-Conceptualization of Matter; Matser.

\section{INTRODUCTION}

From the days of the ancients of Egypt down to the days of Thales, philosophers have always wondered on the fundamental nature of the cosmos. This wonder which was once the search for the us tuff, the all-powerful substance that was responsible for everything else in the world, later became plural and subsequently became a dichotomy of mind and the matter. Neither philosophers nor scientists have been able to explain satisfactorily, the fundamental nature of the cosmos. Yet none has given up on the quest to un-riddle the cosmos. New discoveries and new modes of thinking keep shaping the quest for the interpretation of the universe, displacing previously held beliefs and bringing the universe closer to the ambient of a comprehensive, satisfactory rational interpretation, year after year.

In the world are clear and irrefutable evidences of intelligence, order, organization and comprehensibility. The cosmos is definitely intelligible. Could the intelligibility of the cosmos be a mere product of chance; or a manifestation of an intelligent maker, workman or artificer? How could the world just make itself? How could the cosmos be a product of chance and still be largely orderly? The entire enterprise of science runs on the unquestionable belief in the inherent orderliness of the cosmos. Science aims at discovering the laws of this order. If there were no order in nature; scientific laws would not be possible. Science itself would be impossible. The sun could chose 
to rise in the east today and rise in the west tomorrow. Gravity could not be subject to any laws as moving bodies could behave as they pleased. Life in its entirety would be chaotic. But that is not the case. An ordered cosmos is an indubitable reality.

Wonder led a sizeable number of philosophers and cosmologists to propound that the world is fundamentally non-material in nature. That it is a product of mind. This position is later strengthened by the scientific belief that every effect must have a cause. In so thinking, the world couldn't have possibly come out on its own. It must have been the product of a god or a mind. This belief has its root in the tradition that views man as a soul possessing entity (Plato, c. 360 BC). If man is made of soul and body, the world at large should also have a spiritual component.

But a thoroughly material world would render the theory of divinity meaningless. A material world has no place for a god or God. Some idealists however, acknowledge a nonmaterial agent as the author of the world but do not ascribe divinity to the agent (Plato, c. 360 BC). Some thinkers however, view the world as divine as well as the author of itself. Prominent among them is Baruch Spinoza. For Spinoza, there is no existence beyond nature. Nature itself is divine (Gottlieb, 1999). The materialists' divide sees the cosmos as nothing but pure matter. There is nothing fundamentally non-natural about it. Everything is material. The universe is neither a work of a god nor of an external mind. Some materialists acknowledge intelligence in nature but view it as an attribute of matter (Nkrumah, 1964). In this scheme of thought, the mind is deemed to be fundamentally material (Nkrumah). The cosmos is viewed as having no purpose beyond itself (Sartre). The principle of intelligence in man and in matter orders and organizes the randomness and chaos that abound in the cosmos. God or gods apparently have no place in this cosmology.

The materialist school of thought relies on science for the validation of its propositions. Science interprets phenomena with near accuracy without any reference to any god, demon or God. It simply observes the behavior of nature and forms general rules or theories from its discoveries. These theories remain functional without any dependence on, or any interference from a god or mind. There is no gainsaying that the spiritual or the immaterial has no place in science. Yet, the natural world generally conforms to scientific laws. Is there any need looking for answers to the puzzles of the world beyond the material; or are there certain phenomena that the materialist account has not sufficiently explained?

The reality of mind, the presence of spontaneity and purpose in nature put a hole in the traditional materialistic conception of phenomena. Matter couldn't have been inert and spontaneous at the same time. Purpose suggests volition. The idealists came to the conclusion that phenomena were fundamentally mental. Ideas, not matter, hold the keys to reality. Berkeley took the position further in his famous proclamation "esse is precipi", to be is to be perceived (Berkeley, 1709). All our knowledge of the world take place in our minds. The world is what our minds say they are. Therefore, ideas thought idealists, ought to be the fundamental realities. But denying the concreteness will lead to manifest absurdity.

The problem is obviously linguistic. Reality is there. It is what it is. We are struggling to encompass it with concepts. Neither of the traditional concepts "spirit" nor 'matter' could encapsulate phenomena adequately. Hence, the need in this work to represent phenomena with a more encompassing concept, "matsa' which captures without logical contradictions, those attributes of reality that are called spirits, and also those that are called matter.

The Cosmos-Knowing Subject

A critical factor to be considered in any discourse on cosmology is the cosmos knowing subject. Although man is part and parcel of the cosmos, the cosmos is certainly different from, and larger than man. There is an ontologically problematic condition that arises when man presents his rendition of the cosmos, as certainly the actual nature of the cosmos. That problematic condition is the limitedness of man. Man by nature has ontological limits. Although the cosmos encompasses man, the cosmos is beyond man. It is larger than man. Man's power to know the cosmos depends on the sensations he receives from his six sense organs and the ability of his brain to process the sensations from these senses. The six senses he processes depend on the acuity of his six sense organs. The organs cannot perform beyond their physiological limits. Take the sense of sight for example, some people's sights that are above the average level of acuity while some have sights that are below the average level of acuity. Supposing that there things that could be seen if the human sight had levels of acuity beyond the physiologically present at the moment?

Can we possibly say that every aspect of the cosmos can be comprehended with the six senses available to man? Does the composition of the cosmos necessarily have to defer to man's capacity to comprehend? Is it necessarily a man-centered cosmos? To assume that the composition of the cosmos necessarily has to be attuned to comprehensibility of man is to presuppose that there is a maker who made the cosmos for the purpose of man. What are the bases for such assumptions?

Is there a possibility of the cosmos having phenomena that would require a seventh or even an eight sense or more to be perceived by man? If the owl or the bat were to define the cosmos, they would probably define it as fundamentally dark. There definition of the cosmos would certainly arise from the limits of the acuity of their senses. It should be borne in the mind that man is still an animal like either of these. Every discussion on the cosmos must factor in the limits of human understanding.

\section{What is the World Made of?}

The world is certainly made of phenomena we call matter and certain phenomena we refer to as mind or spirit. We conceive matter as physical and knowable to the senses while we consider mind as immaterial and unknowable to the senses. But this traditional conception of the cosmos has always been epistemologically problematic. The two phenomena are mutually exclusive. Yet we experience the cosmos as one. The material and immaterial could not possibly logically coexist. The quest to escape these contradictions has let some thinkers to declare the world as thoroughly material, while some thinkers define it as pure idea. Kwame Nkrumah and George Berkeley represent the respective divides. However, it should be kept in perspective that the world did not come into being as a result of these conceptions. Rather, man came about these conceptions in his quest to give a meaningful interpretation to the cosmos.

The question could as well be reframed as, "What is our experience of the world?" We experience the world as it is. The world is made up of itself. Our delineations are attempts at attuning it to our consciousness.

The Ideas-made World according to George Berkeley

Berkeley is the most radical representative of idealism. A thorough analysis of his cosmology would show that 
there are fundamentally three realities in the cosmos: individual human minds, ideas and the universal mind of God. The term "spirit" has the same meaning as mind in his usage. Berkeley conceives minds as simple active beings which perceive ideas. Ideas, he describes as sensations perceived by the mind (Bether, 2008). To be is to be perceived; esse is precipi (Berkeley, 1710). In other words, the cosmos is nothing but a series of ideas perceived by a gigantic mind. It is difficult to rule out cynicism or contradiction in Berkeley's cosmology. While he devotes the greater part of the Principles to denying the intra-mental reality of matter, he declares in the conclusion that he does not deny the independent existence of matter but the notion of matter as a substratum upon which the qualities subsist. He concludes that by his denials, he has not done any harm to the physical world but only denied the theist a fulcrum to launch his attack on God (Berkeley, 1710). This conclusion cannot escape the charge of cynicism. If he does not deny the extra-mental existence of matter at the conclusion of his thesis, what then did he set out to prove? Was he writing a cosmology or a religious apology? The religious contention in the conclusion is obvious. Little wonder Nkrumah sarcastically quipped that the grateful church rewarded Berkeley with a bishopric after his outlandish denial of the extra-mental reality of matter (Nkrumah, 1964).

Beyond the social contention, Berkeley's cosmology was significantly influenced by his 1709 book, An Essay towards a New Theory of Vision. In that book he made a credible analysis of the process of perception, and appropriately came to the conclusion that what we perceive are qualities of an object projected unto the sense (Berkeley, 1709). It is trite in philosophy that "the thing" in itself is unknowable (Kant, 1871). We infer the "substratum" upon which the qualities in here through reflection. We don't observe them through sense experiences. In other words, matter is not knowable via the direct observation of the senses but indirectly through the judgment of the mind on the qualities perceived by the senses. In 1710, Berkeley took this thesis further by denying existence of matter since it cannot be proven empirically.

The Matter-made World According to Kwame Nkrumah

Like Berkeley is to idealism, Nkrumah represents a radical rendition of the materialism. For Nkrumah, ours is a material world. It is a self-contained, uncreated world of matter. Our cosmos has no "outside" we are all inside this one world (1964). The world is not an idea. It is neither anybody's idea nor anybody's project. The world is material experience. Although the world is primarily made of matter, matter undergoes "categorial" conversions. Hence, matter is the primary but not the sole reality in the world. Consciousness, especially self-consciousness is non-material process achieved from matter through categorial conversion.

\section{Nkrumah's Re-Conceptualization of Matter}

Newtonian physics conceived matter as inert and largely passive. Newton's theory of moving bodies robs matter of dynamism and spontaneity (Browne, 1999; Holzner, 2005). Matter was viewed to be devoid of selfactivity. It was seen as an inert quantity that is to be acted upon by other forces. Nkrumah took issues with that. $\mathrm{He}$ conceived matter differently. Drawing extensively from Democritus, Nkrumah put forth a new theory of matter. He would see matter as "a plenum of forces in tension" (Nkrumah, 1964). Nkrumah's matter was imbued of dynamism and spontaneity. Matter in Nkrumah's conception had the capacity for self-motion. In that light, matter would not necessarily need a cause to kick-start its operations. It has inherent order which to that extent implies intelligence (1964). This theory of matter runs counter to the traditional conception of matter which renders matter primarily as a substratum upon which qualities inhere. Nkrumah's re-conceptualization of matter certainly brought in new perspectives in the mind-matter controversy.

Nkrumah conceived matter as being self-moved, and to that extent spontaneous. A self-moved material cosmos would not require a maker. It is imbued of its own motion, spontaneity and causality. In other words, it is a selfcontained entity. Nkrumah did not see the need for an external cause in the formation of the cosmos. Matter by its very nature, did not require it.

Nkrumah also posits the primary but not sole reality of matter in his cosmology. He acknowledges the reality of mind as a form different from matter but however posits that mind is a dialectical offshoot of matter. Matter basically as dynamism of forces in tension (1964). Mind is an outcome of such dialectical tension. Consciousness according to Nkrumah is ultimately reducible without any residues, to the activities and evolutions of matter. Although mind is of a different category from matter, it is ultimately an activity of matter; a form that emerged as the result of categorial conversion of matter. It could not be said to have emerged in the cosmos either with matter or independently of matter. It is a dialectical conversion of matter. Hence, Nkrumah posits a primary but not necessarily sole reality of matter. He is of the view that matter in its dialectical processes is capable of yielding forms other than matter. But of course, if mind is ultimately material, it is fundamentally material. The fallacy in Nkrumah's categorial emergence of mind is that, matter by its very definition cannot admit of non-matter. A conversion from non-matter to matter is not logically possible. All conversions of matter are material. The concept of categorial conversion is a logical absurdity.

\section{MATSER AS A COMPREHENSIVE CONCEPTUALIZA-} TION OF PHENOMENA

Gamut of realities define the traditional conceptions of matter and mind. Hence, the persistence epistemological puzzles thrown up by these conceptions. Although we are in one cosmos, these conceptions tend to bring up dual accounts of the cosmos. They do not suffice. Phenomena are in this section re-conceptualized in a more comprehensive term, "matser". Among the findings of this work is the fact that same phenomena exhibit those attributes we traditionally categorize as material and spiritual. If same phenomena exhibit these attributes which epistemologically cannot abide in one entity without conceptual contradictions, it follows that the traditional conception of reality as mind and matter are patently faulty. Phenomena are better conceptualized as "matser", a term which would imbibe these attributes of reality without any contradiction.

\section{Matser}

In great improvements on Newtonian inert matter, Nkrumah re-introduced and made obvious in the concept of matter, the implied self-motion in Democritus' conception atom. Democritus had stated atoms collided freely in space to form the multitude of things (Russell, 1972). Selfmotion implied spontaneity. Of course, if matter is selfmoved, it is necessarily spontaneous. The presence of these attributes in matter renders traditional conception of matter incomprehensive.

It should be kept in perspective that phenomena are. Humans are only trying to understand them and con- 
ceptualize them with words. Phenomena do not endeavor to imitate words. Words endeavor to imitate phenomena. Phenomena never modify to reflect words. Words modify to reflect phenomena. Phenomena as we experience them can neither be encapsulated in the word spirit nor matter per se. Although, each of these words endeavor to encompass phenomena, none captures comprehensively, all manifestations of phenomena. The fact that these words are mutually exclusive rule out any possibility of merger. The idea of a spirit, defined as non-corporeality existing in a corporeal entity is a linguistic nullity; a manifest contradiction. Spirit is defined non-body. Body and nonbody can never coexist in a single entity. If the cosmos is corporeal, it cannot encompass or interact with the spirit. Even if the spirit did exist, its existence would be inconsequential to the cosmos as by default, it would be incapable of interacting with the cosmos in whatsoever manner.

The word "matser" therefore, is coined fort a comprehensive representation of phenomena. Phenomena are matserial in nature. Ours is a matserial cosmos. Phenomena are neither fundamentally material nor spiritual but matserial. Everything is made of matser. The fact is that all phenomena are not identical. The search for matser is a search for a word that will encapsulate all phenomena in their different manifestations. Even though phenomena are different, they have similarities are their bases. These general features that define phenomena are their fundamental natures. The fundamental nature of phenomena is what is called matser. Matser is characterized by corporeity, being, self-motion, spontaneity, intelligence, convertibility and dynamism.

Attributes of Matser

Discussed in detail in the following subtitles are the attributes of matser.

\section{a. Corporeity}

Matter has body. Whether visible or invisible, matser is always corporeal. There is no such thing as incorporeal matser.

\section{b. Being}

The most fundamental attribute of matser is being. Being is observed only in matser. Even when being is imagined (in the case of angels, gods and demons), they are imagined in matserial forms. Hence, God which is said to be a spirit is often imagined as an all knowing bearded old man. Existence is a characteristic and the manifestation of matser. No matser; no existence.

\section{c. Self-Motion}

At the macro level, matser as the cosmos is selfmoved. The revolutions of the heavenly bodies are automatic. At the micro level, matser is self-moved in the form of radiation. The continuous emissions of radioactive substances is self-motion. Matser also undergoes internal motions as changes in its nature. Volcanoes erupt, moving molten magma away from the subterranean part of the earth to the surface. Animals move about. Plants grow, moving upwards in height. Ice melts. The seas and the rivers are self-moved. There is abundance evidence of self-motion of matser.

\section{d. Spontaneity}

To the extent that matser is self-moved, it is spontaneous. The act of motion is self-originated; therefore spontaneous. Rivers flow spontaneously to seas. Corpuscles are spontaneously emitted from radioactive substances. Trees spontaneously grow in the direction of sunlight. Advanced spontaneity in higher manifestations of matser is expressed as volition. The highest concentration of spontaneity is found in animals as volition.

\section{e. Intelligence}

There is inherent order in matser. If there were no intelligence in matser, science would have been a futile enterprise. The premise of the scientific inquiry is that there are natural laws that guide the operations of phenomena. Laws are intelligent organizations of operations. There is no such thing as lawless matser. All phenomena operate based on certain laws of nature. Intelligence is observed only in matser. Therefore, intelligence is an attribute of matser. However, the degrees of intelligence vary in organizations of matser. In matser that has advanced powers of spontaneity, intelligence is much profoundly manifested.

Irritability is an embodiment of high spontaneity and high intellect. It is manifest in plants and animals, which are sophisticated organizations of matter. Irritability is the basis of the concept of mind. Mind is nothing but the operations higher manifestations of intellect and spontaneity. The highest manifestation of mind is found in man. Accordingly, in man is also found the highest manifestation of intelligence and spontaneity. Phenomena have minds only to the degree of spontaneity and intelligence manifest in them.

\section{CONSCIOUSNESS}

Consciousness is nothing but advanced mind. The mind and matter controversy was birthed by poor analysis of mind. Mind was traditionally seen as an extra-corporeal activity rather than a corporeal activity. Mind not only originates and takes place in the body, is also an activity of the body. There is no possibility of mind without body. Mind is reducible without any residue to body. Contrary Nkrumah (1964), there is no categorial conversion of body to nonbody for body is inherently spontaneous and intelligent. Consciousness is intelligence overcome by advanced spontaneity (volition). The human body is constantly engaged in intelligent activities. Majority of those activities are involuntary, therefore, unconscious. These are actions of limited degree of spontaneity. The body does not possess enough spontaneity over them to make them voluntary, therefore, conscious. Vast operations of the body are in this form. In animals, the respiratory system, the circulatory system, the repair of body cells, the combating of foreign malignant bodies and lots more are involuntary, therefore unconscious. Compared to the unconscious activities of the body, the conscious activities of the body are but minute. Consciousness is achieved in the animal brain, a portion of which exhibits high level of spontaneity. The presence of irritability in plants bequeaths them mind but the absence of brain denies them of consciousness.

In dreams, intelligent activities take place in the brain over which we have no conscious control because of limited spontaneity. In deep dream, we remember nothing at all (quote). However, with increased spontaneity, the body edges towards consciousness leading to a weak conscious desire to control events in the dream. As consciousness increases in the dream, the individual takes more control of events until full consciousness is achieved which results in wakefulness and abrupt termination of the dream.

There is no gainsaying that consciousness is the highest manifestation of matser. It should be noted that the brain might not necessarily be the only part of the human body that exhibits consciousness. There seem to be traces of consciousness at the cellular level of the human body. Body cells behave in fairly semi-autonomous ways. Individual cells possess the capacity for irritability. 
The manifestation of mind in them is not in doubt. They are spontaneous and intelligent in their behavior. The question is of degree. Is there a possibility of minute consciousness in the body cells? If there is, it would mean that a conscious entity could exist in larger conscious entity. Since all body cells have direct connections to the human nervous system, perhaps the units of minute consciousness in the cells coalesce in the brain as the advanced consciousness of the human person. If the above hypothesis holds, the possibility of a cosmic consciousness could not be entirely dismissed.

Cosmic Consciousness Possibility

The facticity of consciousness in the cosmos is sacrosanct. At the very least, it not in contention that there is consciousness in man and animals - two phenomena that are part and parcel of the cosmos. As has been established earlier, the cosmos if full of mind. The cosmos is fundamentally matserial. Mind is a characteristic of matser, and ipso facto, present in everything matserial. Consequently, there is no phenomenon in the cosmos that is devoid of mind. But that is not to say that every object in the cosmos has the same level of mind. Mind manifest in phenomena in varying degrees of complexity and development. It is possible that indeed, the only manifestation of consciousness in the cosmos is seen in animals only, man being the highest manifestation of such.

Conversely, the possibility of a universal mind and consciousness cannot be entirely dismissed. It is generally held that the cosmos is a system. In the words of Parmenides, "being is one" (quote). Science does not propose multiple cosmoses but a single cosmos with multiple planetary systems. The zillions of phenomena in manifestation notwithstanding, the cosmos is deemed to be one and basically interconnected. Could it be that like in animals, components minds in the cosmos coalesce to form single consciousness? Just like the body cells have mind, and are perhaps units of consciousness, are the minds that manifest (no matter the degree) in all phenomena, units that constitute the universal mind? Are the manifestations of consciousness in the cosmos units of the cosmic consciousness?

Is the cosmos conscious of itself? Based on the information available to science today, we cannot answer this question either in the affirmative or in the negative. The individuals cells in the human mind though possess mind, cannot know that the human person is selfconscious. Yet, self-consciousness is impossible in the human person without the mind activities of the individual cells that constitute the human person. Even the individual cells in the human brain cannot know that the human person is self-conscious. Yet, their collective activities make self-consciousness possible. When the analogy above is applied to the cosmos, the possibilities are enormous.

If the cosmos as an entity is conscious, what could possibly be the nature of its consciousness? Certainly, if such consciousness did exist, it would be radically different from the human. Unlike the experience of humans, to the cosmos, externality is not possible. Humans are conscious of the world because the world is external in relation to the human world. By that ontological condition, humans can see themselves as being in the world and separate from the world. When a human person is conscious, he gains knowledge of other human persons and other things in the world external to himself. He also gains knowledge of the operations of his own body to the extent that consciousness awareness can reach. Humans know pain, hunger, thirst, pleasure, and infirmity infirmities in themselves only when they are conscious. When they are not conscious, all these cease to exist in their experience. No person asleep can know the experiences mentioned above.

But if self-consciousness is possible in the cosmos, the cosmos could only be possible of the operations of itself and externality is impossible to it. Simply put, nothing is external to the cosmos. There is neither a phenomenon nor a being external to the cosmos for if such a phenomenon or being did exist, it would be part of the cosmos. If it is not part of the cosmos, it would be inconsequential, incapable of interacting with the cosmos, incapable of being (being is fundamentally matserial), therefore, nonexistent. Invariably, the cosmos could not possibly be conscious of something other than itself. The cosmos could but contemplate the operations of itself if it were conscious.

The Possibility of a God in a Possibly Conscious Cosmos

The possibility of cosmic consciousness ushers in the possibility of a God. If the consciousness in the cosmos coalesced into a universal self-consciousness, that consciousness could be called a God. However, whether it deserved worship or not would be a different question. In principle, we cannot logically dismiss the possibility of a universal consciousness. The possibility of a universal consciousness implies the possibility of a God. A universal consciousness definitely would be more advanced than the human consciousness. But unlike the human consciousness, it cannot gain consciousness of other things because there is nothing other than the cosmos.

The idea that the cosmos is a product of chance is funny for the very reason that absolutely nothing can come out of nothing. The cosmos couldn't have begun. It was always in existence. Existence is a characteristic of the cosmos. The cosmos could not possibly not be. It was always there. It is neither bounded nor finite. If the cosmos were bounded, beyond the boundary would still be a continuation of the cosmos. If it is finite, then it is bounded. For it cannot be finite without definite boundaries.

Infinitude is a characteristic of a God. It is safe to assume with Spinoza (quote) that the cosmos is the God. Of course, a God other than the cosmos is not possible. Nothing could possibly exist except it is part of the cosmos. A cosmic God would be nothing other than the consciousness of the cosmos. It can't possibly be apart from the cosmos. Even when heaven is imagined, it is imagined in cosmic terms. There can't be nothing outside the cosmos. The cosmos has no possibility of an outside.

If the cosmos has a universal mind, would it be controlling events in the cosmos? Certainly, if such a mind did exist, it would have the ability of the mind to be spontaneous and intelligent. To that extent, the cosmic mind by default would be able to control some events in the cosmos while not being in control of greater percentage of events in the cosmos because the cosmos is full of minds.

The cosmic mind-God bears striking resemblance to God in organized religions. The Judaic God is essentially a mind which exists in an exclusive part of the cosmos called heaven (quote). From heaven, the Judaic God is portrayed as directing history by controlling, the minds of men (quote), the geological operations of the earth (quote), biological experiences like diseases and childbirths, and even agricultural experience (quote) to mention but a few. In Christianity which is an offshoot of Judaism, God was viewed essentially much as it was viewed in Judaism. 
However, the concept of God in modern Christianity has altered significantly. God is conceived essentially as an active mind that caused the cosmos (quote), directs history by essentially acting on the minds of men. Heaven is not seen as cosmic location but the gathering of pure minds in the presence of the ultimate mind known as God. Hinduism celebrates the universal mind as the divinity. In Hinduism, the ultimate expectation of man is to merge with the universal consciousness after death (quote).

These religions in their respective ways addressed the problem of consciousness in the cosmos. They all agree that man has individual consciousness which they call soul. These religions believe that consciousness in the form of the soul survives death. They believe in a cosmic consciousness generally called God. They believe that the individual consciousness upon fulfilling certain moral conditions returns to God, the cosmic consciousness at death. While some of the major religions believe that God is extra-cosmic, some believe that God is at one with the cosmos. The entire religious hypotheses lie on the assumption that there is a cosmic consciousness which the individual consciousness would aspire to at death. Without this assumption, there would be no religion. It was at this point that philosophy gave rise to religion.

It appears that early religionists were able to philosophically arrive at a cosmic consciousness other than the individual consciousness. They apparently concluded that since consciousness is neither visible nor tangible, individual consciousness must necessarily survive death and merge with the cosmic consciousness. That was pure philosophy. But religion birthed in when they personalized the cosmic consciousness and offered it worship. There is lies the origin of Gods.

However, in a matserial world, consciousness is a character of the cosmos. It cannot be personalized because the cosmos is infinite. What cannot be defined, what is boundless, what has no borders, what is without an "other", cannot be personalized. Self-consciousness at the cosmic level is not possible. There is no "other" to be contemplated by the cosmos. The consciousness of the cosmos is the consciousness of its operations (Just the way the human person is conscious that he is hungry; that his heart beats; that he has a headache, etc.). Like everything matserial, the cosmos is spontaneous, intelligent, purposeful and conscious. The problem however, is that the cosmos cannot act outside of itself. It is not contained in anything. It simply is. The cosmos has no "outside". All the activities of the cosmos are the activities of itself and itself. That is, nature as it unfolds. In the light of the above hypothesis, the idea of a personalized God though not denied is not possible in a matserial cosmos. God is the conscious, intelligent and purposeful cosmos in its infinity and activity.

The Impossibility of Nothingness

The cosmos is the only existent. It is the nature of the cosmos to be. It cannot not possibly be. Matter is said to be indestructible but convertible (quote). If matter is indestructible, it necessarily follows that it is uncreatable. Its convertibility implies that it can change form but can't be eliminated. In the light of this, the cosmos couldn't have been possibly created. It is not possible for the cosmos to have a beginning neither is possible for it to have an end. Like all matter, it can neither be created nor destroyed. It would always experience conversions but it couldn't have possibly had a beginning.

It the light of this, the Big Bang theory of the origin of the universe would be fallacious. It couldn't possibly be the origin of the universe but a change in the already existing universe. If at all there was a bang, it took place within the cosmos; not in a vacuum. It was nothing more than a conversion of matter: neither a creation nor the beginning of the cosmos.

\section{The Cosmos is the Endpoint of Reality}

There is no point beyond the cosmos. There is no reality beyond the cosmos. These assertions are predicated on the fact that the cosmos has neither an "outside" nor a boundary. It is closer to Anaximander's "indeterminate" (quote). There can't be any purpose beyond the cosmos. All teleology are activities of conversions in the cosmos" the conversions of matser from one state to another. All activities in reality takes place in the cosmos. If God exists, it could either exist within the cosmos or be the cosmos as there are no realities beyond the cosmos. All aspirations of man boil down to the cosmos beyond which there is nothing. This conclusion is inescapable. Even if a part of the cosmos is designated as "God", it is still part and parcel of the cosmos.

\section{PURPOSE IN MATSER}

There is inherent order in nature. Order presupposes purpose. Every system is teleological. The end of the system is the reason for the system. Matser appears in systems. There are higher and lower organizations of matser. Purpose is more readily noticeable in higher organizations of matser. In matser with high consciousness, purposefulness is more advanced. Every act of irritability is act of purpose; even when involuntary. The purpose of the composition of the elements of matser in a certain way is to be that thing it is. Hence, it has been ordered thus. The purpose of the circulatory system, among other things is to circulate oxygen and energy to all parts of the body. The purpose of the sight system is to see. The retina, the iris and the relevant parts of the brain are all ordered for that purpose. The purpose of the tree bending away from the shade towards the direction of sunlight is to receive energy. All animals exhibit purposeful activities.

But the cosmos could not possibly have any purpose beyond its activities for there are no realities beyond the cosmos. It could not possibly be teleological to anything beyond itself.

\section{Life in Matser}

Matser is in perpetual conversion. All matser are always converting from one form to another. There is an inherent dynamism of grow and decay in the cosmos. All these are dynamic conversions of matser in the cosmos. To the extent that all matser undergo conversions, all matser are alive. The degrees of complexity of life in matser vary significantly however. Life is basically matserial even at the most complex manifestation. The cosmos therefore, is alive. Death of matser not possible but conversion of a highly dynamic and complex of matser of matser to something else could result in the death of that system as it previously functioned. This is what happens at the death of plants and animals.

When a plant or an animal dies, it means it can no longer function as that system of matser, No matser is lost in the cosmos as the result of this death but the composites of the system are converted to order forms of matser. A dead animal or plant decays and its composites merge with the environment and ecosystem. The composite elements return to nature. In the final analysis, life in its complex forms is a unique process of continuous conversion of matser. 


\section{CONCLUSION}

The cosmos has always been. But our interpretations of it continue to improve as we gain more insights into its nature. The mind-matter interpretation of the cosmos created logical dichotomies that split the cosmos into two intellectually irreconcilable folds. It should be borne in mind that our interpretations of the cosmos do not change it but informs our conscious attitudes to it. The cosmos is; our thoughts whatever about it notwithstanding.

The reconceptualization of reality as matser rather than mind and matter, removes intellectual absurdities that lead to the dichotomization of reality. The novel interpretation simulates reality as we experience it. A unity rather than a duality. It draws attention to attributes of matter which were previously conceptualized separated from matter as spirits. This work proves conclusively that these phenomena are indeed same. Neither matter nor spirit could adequately express this discovery. Hence, the neologism, "matser".

\section{REFERENCES}

Berkeley, G. (1709). An Essay towards a New Theory of Vision. Dublin. Retrieved from https://www. maths.tcd.ie/ dwilkins/ Berkeley/Vision/1709A/Vision.pdf (In English)

Berkeley, G. (1710). A Treatise Concerning the Principles of Human Understanding. Dublin. Retrieved from https:// www. maths.tcd.ie/ dwilkins/Berkeley/HumanKnowledge/1734/ HumKno.pdf (In English)

Bether, T. M. (2008). Berkeley: A Guide for the Perplexed. Continuum Publishing. London New York. (In English)

Browne, M. E. (1999). Schaum's outline of theory and problems of physics for engineering and science. Schaum's Outline Series. McGraw-Hill Companies. p. 58. (In English)

Downing, L. (2013). George Berkeley. The Stanford Encyclopedia of Philosophy. Retrieved from https://plato.stanford.edu/ entries/berkeley/ (In English)

Gottlieb, A. (1999, July 18). God exists, philosophically (review of "Spinoza: A Life" by Steven Nadler). The New York Times. Retrieved from http://movies2.nytimes.com/books/99/07/18/ reviews/990718.18gottlit.html (In English)

Bloom, H. (2006, June 16). "Deciphering Spinoza, the great original. A review of R. Goldstein. Betraying Spinoza. The Renegade Jew Who Gave Us Modernity. The New York Times. Retrieved from https://www.nytimes.com/2006/06/18/books/review/ 18bloom.html (In English)

Holzner, S (2005). Physics for Dummies. Wiley, John \& Sons, Incorporated. p. 64. (In English)

Kant, I. (198). Critique of Pure Reason. Cambridge University Press. Retrieved from http://strangebeautiful.com/other-texts/kantfirst-critique-cambridge.pdf (In English)

King James Bible Version: Daniel 4.17; Genesis 1.2; Genesis 1.28 ; 1 Kings 8.27

McGuire, J. E. (1972). Boyle's conception of nature. Journal of the History of Ideas, 33(4), 523-542. (In English)

Michael, P. (Ed.). (2000). Theism and Humanism. Seattle. (In English)

Nkrumah, K. (1964). Consciencism: Philosophy and Ideology for Decolonization. Retrieved from https://consciencism.files.wordpress.com/2016/12/consciencism-philosophy-and-ideologyfor-de-colonisation-20161.pdf (In English)

Plato (c. 360 BC). Phaedo. Translated by Benjamin Jowett. Retrieved from http://classics.mit.edu/Plato/phaedo.html (In English)

Plato (c. 360 BC). Timaeus. Translated by Benjamin Jowett. Retrieved from https://susanwisebauer.com/story-of-science/ plato-timaeus-c-360-bc/ (In English)

Russell, B. (1945). A History of Western Philosophy. Simon \& Schuster. Retrieved from http://www.ntslibrary.com/PDF\%20Books/History\%20of\%20Western\%20Philosophy.pdf (In English)
Sartre, J. (1948). Existentialism and Humanism. SOLD Publisher.

Sepharial. (n.d). Second Sight: A Study of Natural and Induced Clairvoyance. United States: Library of Alexandria.

Spinoza, B. (1883). Correspondence.

Thrane \& Susan. (2010). Hindu end of life death, dying, suffering, and karma. Journal of Hospice and Palliative Nursing, 12(6), 337-342. DOI: https://doi.org/10.1097/njh.0b013e3181f2ff11 (in English).

\section{LIST OF REFERENCE LINKS}

Berkeley G. An Essay towards a New Theory of Vision. Dublin, 1709. URL: https://www.maths.tcd.ie/ dwilkins/Berkeley/Vision/ 1709A/Vision.pdf (Дата звернення: 11.10.2018)

Berkeley G. A Treatise Concerning the Principles of Human Understanding. Dublin, 1710. URL: https://www.maths.tcd.ie/ $\sim$ dwilkins/Berkeley/HumanKnowledge/1734/HumKno.pdf (Дата звернення: 08.10.2018)

Bether T. M. Berkeley: A Guide for the Perplexed. London, New York: Continuum Publishing, 2008.

Browne M. E. Schaum's outline of theory and problems of physics for engineering and science. Schaum's Outline Series. McGraw-Hill Companies, 1999. p. 58.

Downing L. George Berkeley. The Stanford Encyclopedia of Philosophy. 2013. URL: https://plato.stanford.edu/entries/berkeley/ (Дата звернення: 16.10.2018)

Gottlieb A. God exists, philosophically (review of "Spinoza: A Life" by Steven Nadler). The New York Times. 1999, July 18. URL: http://movies 2. nytimes.com/books/99/07/18/reviews/ 990718.18gottlit.html (Дата звернення: 03.08.2018)

Bloom H. "Deciphering Spinoza, the great original. A review of R. Goldstein. Betraying Spinoza. The Renegade Jew Who Gave Us Modernity. The New York Times. 2006, June 16. URL: https:// www.nytimes.com/2006/06/18/books/review/18bloom.html (Дата звернення: 06.09.2018)

Holzner S. Physics for Dummies. Wiley, John \& Sons, Incorporated, 2005, p. 64. (In English)

Kant I. Critique of Pure Reason. Cambridge University Press. Reprint 1871. URL: http://strangebeautiful.com/other-texts/kantfirst-critique-cambridge.pdf (Дата звернення: 01.10.2018)

King James Bible Version: Daniel 4.17; Genesis 1.2; Genesis 1.28; 1 Kings 8.27

McGuire J.E. Boyle's conception of nature. Journal of the History of Ideas. 1972. 33(4), 523-542.

Michael P. (Ed.). Theism and Humanism. Seattle, 2000.

Nkrumah K. Consciencism: Philosophy and Ideology for Decolonization, 1964. URL: https://consciencism.files.wordpress.com/2016/12/consciencism-philosophy-and-ideology-for-decolonisation-20161.pdf (Дата звернення: 23.09.2018)

Plato (c. 360 BC). Phaedo. Translated by Benjamin Jowett. URL: http://classics.mit.edu/Plato/phaedo.html (Дата звернення: 13.10.2018)

Plato (c. 360 BC). Timaeus. Translated by Benjamin Jowett. URL: https://susanwisebauer.com/story-of-science/plato-timaeusc-360-bc/ (Дата звернення: 16.10.2018)

Russell B. A History of Western Philosophy. Simon \& Schuster, 1945. URL: http://www.ntslibrary.com/PDF\%20Books/ History\%20of\%20Western\%20Philosophy.pdf (Дата звернення: 06.10.2018)

Sartre J. Existentialism and Humanism. SOLD Publisher, 1948.

Sepharial. (n.d). Second Sight: A Study of Natural and Induced Clairvoyance. United States: Library of Alexandria.

Spinoza B. Correspondence. Reprint 1883.

Thrane \& Susan. Hindu end of life death, dying, suffering, and karma. Journal of Hospice and Palliative Nursing, 2010. 12(6), 337-342. DOI: https://doi.org/10.1097/njh.0b013e3181f2ff11 (Дата звернення: 08.10.2018). 
Ебо Сократ,

Інститут фундаментальних досліджень,

Федеральний університет Отуоке (Баєлса, Нігерія)

e-mail: eboss@fuotuoke.edu.ng, ORCID 0000-0003-4062-8487

\section{МАЙСТЕРНІСТЬ СВІТОБУДУВАННЯ: НОВА КОНЦЕПТУАЛІЗАЦІЯ СПРАВИ І ДУХУ}

У статті переусвідомлюються домінуючі онтологічні та епістемологічні інтерпретації Всесвіту, включаючи матеріалістичні та ідеалістичні варіанти. На прикладі філософських поглядів, 3 одного боку, ганського мислителя, політичного діяча Кваме Нкруми та ірландського філософра, єпископа Джорджа Берклі, 3 іншого, автор демонструє неможливість досягнення компромісу між названими світоглядними картинами світу. Матеріалісти бачать світ як по суті матеріальний, позбавлений Бога чи творця. Ідеалісти бачать світ як продукт духу або розуму. Вони вважають, що світ є принципово нематеріальним. Обидві позиції не можуть задовольнити дослідників Всесвіту. Адже космос є, існує, незалежно від його інтерпретації. Спираючись на текстологічні дослідження та спекулятивний філософський аналіз, автор доводить, що так звана амбівалентність космосу з протиставленням матеріального та духовного має штучний характер і не виходить за межі епістемології. Якщо світ є матеріальним, він, безумовно, не є ідеальним; якщо все зроблено тільки 3 ідей, то це, безумовно, нематеріальне. У реальності ж існує чимало явищ, які не можна класифікувати виключно як матеріальні або духовні. Тоді виявляється, що існуюче визначення матерії не охоплює деяких властивостей, притаманних явищам, які класифікуються як "матеріальні". Так само може бути, що те, що називається "духовним", - це атрибути, властивості, суть яких не вичерпується визначенням того, що ми називаємо матерією. Ми могли б також жити в космосі, який складається з речовин, властивостями яких є ті, що ми мислимо як "матеріальні", а деякі з них ми вважаємо "духовними". Автор доходить висновків, що філософи традиційно поділяють явища реального світу на матеріальні та духовні, але якщо явища демонструють атрибути, які епістемологічно не можуть перебувати в одній сутності без концептуальних суперечностей, звідси випливає, що традиційна концепція реальності як розуму і матерії є явно недостатньою. Космос не складається виключно з матерії або духу. Раціональна концептуалізація реальності логічно призводить до протиставлення матерії і духу, тоді як сама залишається неподільною цілісністю. У статті лунає заклик переглянути чинне поняття матерії й існуючу концепцію духу, узагальнити їх в категорії "матсер" (тобто до матерії додається літера "с", що вказує на дух (спірит)), яка знімає інтелектуальну абсурдність дихотомізації реальності. Ми знаходимося в одному космосі, який "подвоюється" лише в мові, але не в нашому досвіді. Наш досвід космосу залишається єдиним. Ми - це "матсерний космос".

Ключові слова: свідомість космосу; створений ідеями світ; Берклі; створений матерією світ; Нкрума; ре-концептуалізація матерії; матсер.

\footnotetext{
(c) Ebo Socrates

Надійшла до редакції: 12.11.2018

Прийнята до друку: 04.02.2019
} 